\title{
A method for measuring electrical signals in a primary cilium
}

\author{
Nancy K Kleene and Steven J Kleene
}

\begin{abstract}
Background: Most cells in the body possess a single primary cilium. These cilia are key transducers of sensory stimuli, and defects in cilia have been linked to several diseases. Evidence suggests that some transduction of sensory stimuli by the primary cilium depends on ion-conducting channels. However, the tiny size of the cilium has been a critical barrier to understanding its electrical properties. We report a novel method that allows sensitive, repeatable electrical recordings from primary cilia. Adherent cells were grown on small, spherical beads that could be easily moved within the recording chamber. In this configuration, an entire cilium could be pulled into a recording microelectrode.

Results: In $47 \%$ of attempts, suction resulted in a seal with high input resistance. Single channels could be recorded while the cilium remained attached to the cell. When the pipette was raised into the air, the cell body was pulled off at the air-bath interface. The pipette retained the cilium and could then be immersed in various solutions that bathed the cytoplasmic face of the membrane. In excised cilia, ionic currents through ciliary channels were modulated by cytoplasmic $\mathrm{Ca}^{2+}$ and transmembrane voltage.
\end{abstract}

Conclusions: Ciliary recording is a direct way to learn the effects of second messengers and voltage changes on ciliary transduction channels.

\section{Background}

Most cells in the body possess a single primary cilium [1], a thin process that projects from the surface of the cell. Defects in primary cilia are implicated in a wide range of human pathologies [2-5], including cystic kidney disease [6]. Primary cilia are thought to be cellular antennae; they detect chemical, mechanical, osmotic, and gravitational stimuli [7-11]. Evidence indicates that some sensory stimuli may be transduced into electrical signals via ion channels in primary cilia (for examples, see $[12,13])$. Several channel proteins (TRPP2, TRPC1, TRPV4, $\alpha$-epithelial sodium channel) have been localized to primary cilia [8,14-18]. Additional channels have been studied in specialized cilia from other cells (for example, sperm [19], Chlamydomonas [20], photoreceptors [21], and olfactory receptor neurons $[22,23]$ ) or found in the ciliary proteome [24-27].

Because of the primary cilium's tiny size, direct examinations of the transduction of sensory to electrical

\footnotetext{
* Correspondence: steve@syrano.acb.uc.edu

Department of Cancer and Cell Biology, University of Cincinnati, PO Box 670521, Cincinnati, OH, 45267-0521, USA
}

signals in primary cilia are virtually non-existent. Instead, hypotheses of ciliary sensory function have been inferred from protein localizations, loss-of-function studies, and the effects of damaging or removing cilia $[12,15,28]$. There is now a substantial body of research characterizing the properties of ion channels relevant to primary cilia. Most investigators have taken indirect approaches, studying channel subunits expressed exogenously $[17,29-33]$ or in artificial bilayers $[13,16,30,34]$, or channels in non-ciliary cellular compartments $[30,32,34]$. The conclusions are sometimes noted to be contradictory [35-37], and it is difficult to guess how the channels might function in the native cilium. This limitation was acknowledged and addressed directly by Raychowdhury et al. $[13,16]$. Their investigations revealed channels in primary cilia isolated from cultured renal epithelial cells. To the best of our knowledge, their two reports are the only published recordings from the native membrane of any primary cilium.

Vision and olfaction also use specialized sensory cilia, and direct recordings from those cilia have long been abundant. It has been suggested that similar approaches 
might benefit research into primary cilia [4]. In 1991, we learned how to record from single olfactory cilia [38]. We have now adapted that method to allow sensitive, repeatable, and stable electrical recordings from single primary cilia, either cell-attached or immediately following detachment from a living cell. Our new method provides a direct means to investigate electrical signaling in the membrane of a primary cilium.

\section{Methods}

\section{Cell culture}

What follows is a description of the optimized culture and harvesting methods. mIMCD-3 cells (murine renal epithelial cells from the inner medullary collecting duct, CRL-2123, American Type Culture Collection, Manassas, VA USA [39]) were passaged weekly onto culture plastic with a $1: 4$ to $1: 8$ subcultivation ratio. The culture medium was Dulbecco's modified Eagle's medium (DMEM)/F12 (MT10092CV, Thermo Fisher Scientific, Waltham, MA USA) with $10 \%$ fetal bovine serum (SH30910.03, Thermo Fisher Scientific) and antibiotics (final concentrations 100 units $/ \mathrm{mL}$ penicillin and $0.1 \mathrm{mg} / \mathrm{mL}$ streptomycin, SV30010, Thermo Fisher Scientific). Cells were incubated at $37^{\circ} \mathrm{C}$ in $95 \%$ air and $5 \%$ carbon dioxide.

The glass-coated beads (G102-<90, SoloHill Engineering, Ann Arbor, MI USA), were combined with distilled water (to $8 \mathrm{mg} / \mathrm{mL}$ ) in a scintillation vial and autoclaved. For each milliliter of final chamber volume, $11.6 \mu \mathrm{L}$ of the bead and water mixture was combined with $88.4 \mu \mathrm{L}$ of medium in a sterile microcentrifuge tube and incubated at $37^{\circ} \mathrm{C}$ for at least $1 \mathrm{~h}$. The autoclaved Teflon chambers were placed in a sterile Petri dish and incubated at $37^{\circ} \mathrm{C}$ for at least $1 \mathrm{~h}$. Cells were dissociated with $0.05 \%$ trypsin/ ethylenediaminetetraacetic acid (SH3023601, Thermo Fisher Scientific) for about $10 \mathrm{~min}$. The dissociation was ended by the addition of medium with trituration. The cells were centrifuged at $300 \times g$ for $5 \mathrm{~min}$, liquid was removed, and the cells were resuspended in fresh medium with trituration. Cells (final, $2 \times 10^{5}$ cells $/ \mathrm{mL}$ ), medium, and beads (final, $0.09 \mathrm{mg}$ beads/mL, approximately 550 beads $/ \mathrm{mL}$ ) were placed in a depression that had been milled into a Teflon block (Figure 1E, 8735K67, McMaster-Carr, Robbinsville, NJ USA). The external dimensions of the block were $76 \mathrm{~mm} \times 26 \mathrm{~mm} \times 13 \mathrm{~mm}$; the dimensions of the depression were $65 \mathrm{~mm} \times 17 \mathrm{~mm} \times 11 \mathrm{~mm}$. We used about $0.5 \mathrm{~mL}$ of cell suspension per square centimeter of Teflon chamber floor. The cells and beads were gently shaken for a few seconds every 15 min for the first $90 \mathrm{~min}$ of culture. We subsequently dispersed the beads with a cell lifter (70-2180, Biologix, Lenexa, KS USA); this significantly decreased the clumping of the beads. Cell-coated beads were usually used for recording after 10 to 15 days in culture. We used passages 17 to 31 .
Half of the growth medium was replaced every 2 to 3 days. To replace the medium, the chamber was held at an incline to give the beads time to settle before half of the medium was replaced. Chambers with a siliconized glass (Sigmacote, Sigma-Aldrich, St. Louis, MO USA) bottom were occasionally used, but we did not determine that they were better than Teflon chambers. However, they did permit monitoring of the culture more easily than the opaque Teflon, and at least some of the beads were free of the monolayer. In pilot studies, hollow borosilicate glass beads with a $10 \mu \mathrm{m}$ diameter (AGSCO Corporation, Wheeling, IL USA) appeared to be engulfed by the cells and no cilia were visible.

On the day of use, half of the old medium was replaced with new. Then the Teflon chamber was held at an incline and the beads were allowed to settle before about $70 \%$ of the medium was removed. Next the chamber was tipped to gather beads near one end. Medium and beads were transferred to the well of a plastic culture plate (Nunc 176740, Thermo Fisher Scientific). The well had been pretreated with medium to reduce sticking. Eight rinses with sterile Ringer (see below for composition) were usually sufficient to remove debris and serum without damaging cilia or stripping the cells from the beads. Rinsing consisted of removal of all but about $270 \mu \mathrm{L}$ of the fluid followed by the addition of $550 \mu \mathrm{L}$ of Ringer. The Ringer was heated to $37^{\circ} \mathrm{C}$ and then allowed to cool to room temperature as aliquots were removed for rinsing. Rinsing beads in the plastic well allowed us to use the microscope to ensure that most of the beads returned to the bottom before removing fluid. We removed large clumps of cells or beads with tweezers. The beads and a minimal volume of Ringer were transferred to the recording chamber.

\section{Visualizing the cilia}

To see the cilia during recording, we used a non-infinity-corrected, inverted microscope (Diaphot, Nikon, Tokyo, Japan) with a $40 \times$ Plan, phase-contrast objective (numerical aperture (NA) 0.7, DL, Ph3, Nikon), 15× ocular lenses (CFW, Nikon), and an extra-long-workingdistance condenser (78924, NA 0.3, working distance $54 \mathrm{~mm}$, Nikon). Phase-contrast microscopy cannot be used to visualize cilia lying above other cells or debris, so it was important that the bottom of the recording chamber (a cover glass) be clean. The cover glass was pretreated with filtered bovine serum albumin $(10 \mathrm{mg} / \mathrm{mL})$; this prevented the cell-coated beads from adhering to the glass [40]. A minority of the cilia had a small vesicular enlargement, usually at the distal tip (for example, cell 1 of Additional file 1).

As we learned to recognize the cilia and optimized the optics, it was helpful to use a fluorescent membrane dye to improve visibility. The dye, di-8-ANEPPS (D3167, 

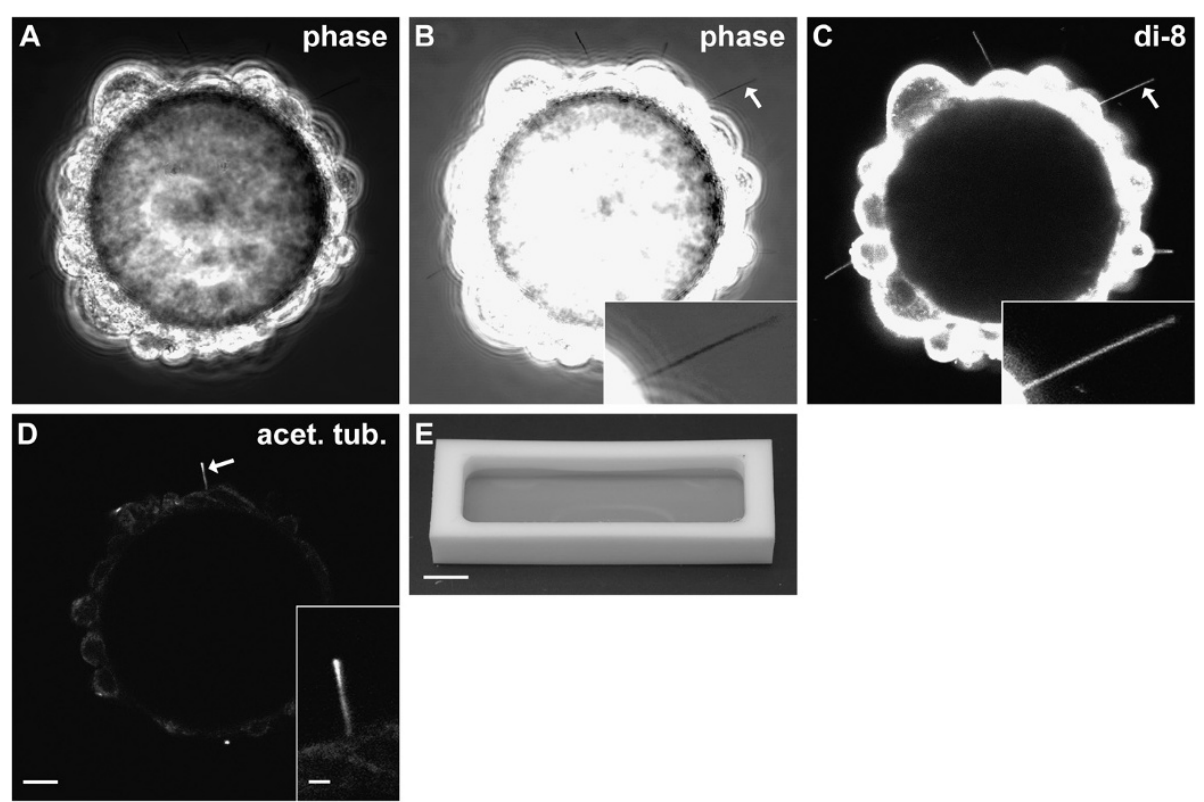

Figure 1 Culture system for the growth of ciliated cells on beads. (A-B) Phase-contrast image of live cells on a bead with contrast set to show cell bodies (A) or cilia (B). (B inset) Enlargement of cilium indicated by arrow. (C) Fluorescent image of bead from $\mathbf{A}$ and $\mathbf{B}$ labeled with di-8-ANEPPS (di-8). (C inset) Enlargement of cilium indicated by arrow. (D) Fluorescent image of a cell-coated bead fixed and immunolabeled for the ciliary marker acetylated a-tubulin (acet. tub.). (D inset) Enlargement of cilium indicated by arrow. (E) Teflon chamber with medium. $\operatorname{Bar}=10 \mu \mathrm{m}(\mathbf{A}-\mathbf{D}), 2 \mu \mathrm{m}$ (B-D inset), $1 \mathrm{~cm}(\mathbf{E})$.

Invitrogen / Life Technologies, Carlsbad, CA USA), was chosen because of its ability to label the membrane of live cells; we did not use its voltage-sensing properties. We mixed $1 \mu \mathrm{L}$ of di-8-ANEPPS $(1.7 \mathrm{mM}$ stock in dry dimethyl sulfoxide) with $2.4 \mu \mathrm{L}$ of $10 \%$ pluronic acid (Invitrogen / Life Technologies, P6866) before adding $497 \mu \mathrm{L}$ of Ringer. Cell-coated beads were rinsed in Ringer, and $40 \mu \mathrm{L}$ of the bead/Ringer mixture was added to the dye solution (final concentrations: $3 \mu \mathrm{M}$ di-8ANEPPS and $0.04 \%$ pluronic acid) for $20 \mathrm{~min}$ before rinsing again with Ringer. When dissolved in membrane, di-8-ANEPPS excites maximally at $465 \mathrm{~nm}$ and emits maximally at $635 \mathrm{~nm}$. On the recording setup (described above), stained cilia were visualized with a fluorescein isothiocyanate (FITC) filter cube (DM510, Nikon) with a long-pass emission filter (BA515IF, Nikon). Cells used for electrical recording were never exposed to di-8ANEPPS.

\section{Immunocytochemistry}

Cell-coated beads were rinsed with DMEM/F12 and fixed for $15 \mathrm{~min}$ by adding $500 \mu \mathrm{L}$ of $4 \%$ paraformaldehyde in $0.1 \mathrm{M}$ phosphate buffer $\left(30 \mathrm{mM} \mathrm{KH}_{2} \mathrm{PO}_{4}, 0.1 \mathrm{M}\right.$ $\mathrm{Na}_{2} \mathrm{HPO}_{4}, \mathrm{pH}$ 7.2) to about $120 \mu \mathrm{L}$ of beads and medium. The beads were rinsed with phosphate-

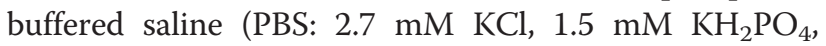
$8.1 \mathrm{mM} \mathrm{Na}_{2} \mathrm{HPO}_{4}, 140 \mathrm{mM} \mathrm{NaCl}, \mathrm{pH} 7.4$ ) and blocked for 20 min with $2 \%$ normal rabbit serum, $0.1 \%$ Triton X-
100 , and $0.02 \%$ sodium azide in PBS. The monoclonal anti-acetylated $\alpha$-tubulin antibody (mouse isotype IgG2b, ascites fluid, clone 6-11B-1, T6793, Sigma-Aldrich) had been raised against acetylated $\alpha$-tubulin from the outer arm of Strongylocentrotus purpuratus (sea urchin). This antibody was diluted to $1 / 15,000$ in antibody diluting buffer $(0.2 \%$ Triton X-100 and $0.02 \%$ sodium azide in PBS). The antibody was applied for $1 \mathrm{~h}$ at room temperature. After rinsing with PBS, the fluorescently labeled rabbit anti-mouse antibody (Alexa 488, Jackson ImmunoResearch Laboratories, West Grove, PA USA, 1/ 500 in the antibody diluting buffer) was applied for 15 min. After rinsing in PBS, the beads were mounted with Fluoromount-G (SouthernBiotech, Birmingham, AL USA). The cilium in Figure 1D is fairly straight and long, but cilia usually became shorter and less straight during fixation.

\section{Image acquisition and processing}

Images for Figures 1A-D were acquired on an inverted, confocal microscope (LSM 710, Karl Zeiss AG, Oberkochen, Germany) and exported as TIFF files using Zen 2009 Light Edition (Zeiss). Figures $1 \mathrm{~A}-\mathrm{C}$ were acquired with a $40 \times / 0.75$ NA, Plan-Neofluar, phase-contrast objective, 1400 pixels $\times 1400$ pixels, $97 \mathrm{~nm} \times 97 \mathrm{~nm} \times 1,000 \mathrm{~nm}$ voxel dimensions, and 8-bit depth. The laser wavelength was $488 \mathrm{~nm}$. For Figures $1 \mathrm{~A}, \mathrm{~B}$, the transmission channel was used. For Figure 1C, the dichroic mirror was set for 
$488 \mathrm{~nm}$ and the emission filter was 535 to $759 \mathrm{~nm}$. Figure 1D was acquired with a $63 \times / 1.20 \mathrm{NA}$, C-Apochromat, water-immersion objective, 1,188 pixels $\times 1,188$ pixels, $114 \mathrm{~nm} \times 114 \mathrm{~nm} \times 900 \mathrm{~nm}$ voxel dimensions, with 8bit depth. The laser wavelength was $488 \mathrm{~nm}$, the dichroic mirror was set for $488 \mathrm{~nm}$, and the emission filter was 493 to $630 \mathrm{~nm}$. Figure $1 \mathrm{E}$ was acquired with a Nikon D70 single-lens reflex camera. For Figure 1, Adobe Photoshop 6.0 was used for converting to grayscale, cropping, resizing, and adding labels. Photoshop was also used to adjust brightness and contrast, including gamma, via 'Input Levels'. Figures $1 \mathrm{~A}-\mathrm{C}$ were resampled from 97 to $114 \mathrm{~nm} /$ pixel X-Y resolution to match the resolution of Figure 1D so that the same scale bar could be used for all four images. Inserts for Figures 1B-D were resampled to match the greater resolution of the main figures. Figure $1 \mathrm{E}$ was resampled to match the greater resolution of Figure 1A-D. The videos in Additional file 1 were acquired with a camera (WV-CD50, Panasonic, Osaka, Japan), 1× TV relay lens (Nikon), and a digital video recorder (RDR-VX530, Sony, Tokyo, Japan). The videos were processed in mencoder (http://www.mplayerhq.hu) to increase gamma and contrast. Figure 2 is the average of two sequential frames from Additional file 1, cell 2. Photoshop was used to crop and add the yellow arc and calibration bar to Figure 2 .

\section{Electrical recording}

To record from intact single renal primary cilia, we modified a method developed for patch-clamping frog olfactory cilia $[38,40]$. Under phase-contrast microscopy at $600 \times$ magnification, a single primary cilium at least $10 \mu \mathrm{m}$ in length was located. The tip of a recording micropipette was positioned near the distal tip of the cilium. Suction was applied through the pipette until the

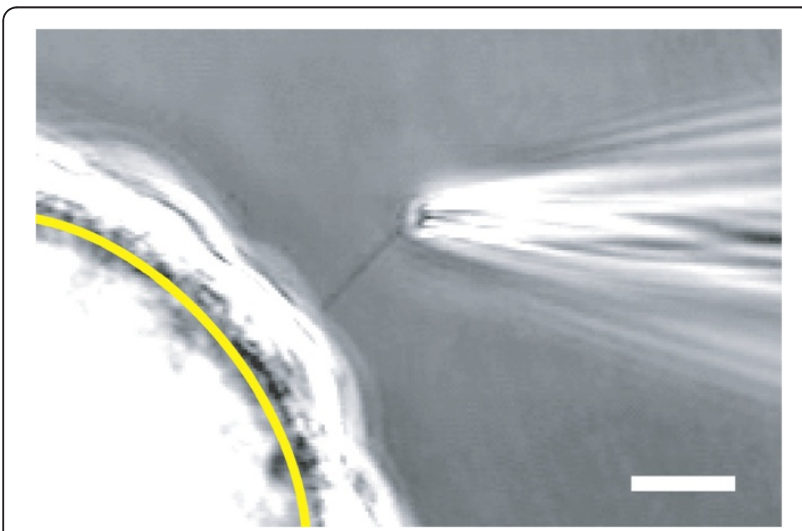

Figure 2 Photomicrograph of the method for electrical recording from an isolated primary cilium. A glass-coated bead is covered with a confluent layer of mIMCD-3 cells. The yellow line represents the boundary between the bead and the cells. One primary cilium of one cell is visible entering the tip of the recording pipette. $\mathrm{Bar}=10 \mu \mathrm{m}$. cilium began to enter the pipette. Entry of the cilium into the pipette was confirmed as follows. When half of the cilium had entered the pipette, the pipette was slowly moved back and forth in a direction perpendicular to its length. When the cilium had truly entered the pipette, it moved with the tip of the pipette, sometimes rotating the bead in the process (Additional file 1). We have generally been unable to perform this test with cilia shorter than $10 \mu \mathrm{m}$. Additional suction was applied until the rest of the cilium entered the pipette and a highresistance seal formed near the base of the cilium. The resistance sometimes increased over a period of several minutes, and suction up to $-200 \mathrm{mmHg}(-27 \mathrm{kPa})$ was used to make a seal. Only rarely did the membrane break to give a whole-cell recording. In most experiments, the pipette containing the cilium was then raised into the air and quickly re-immersed into a pseudointracellular solution. This served to excise the cilium from the cell, leaving the entire cilium inside the pipette in the inside-out recording configuration. In a few cases, this caused a loss of the high-resistance seal. Cilia were not studied further unless the input resistance (measured in the standard recording solutions described below) was at least $1 \mathrm{G} \Omega$. The recording was often stable for at least $30 \mathrm{~min}$, and it was routinely possible to transfer the pipette containing the excised cilium through the air to a series of baths containing different pseudointracellular solutions. A recording chamber built for this purpose has been previously described [40].

Recording micropipettes were pulled in two stages on a 700D vertical puller (David Kopf Instruments, Tujunga, CA USA) from capillaries of 8250 glass, a Schott borosilicate glass. Capillaries were fabricated by King Precision Glass, Inc. (Claremont, CA USA) to the dimensions outside diameter (OD) $1.5 \mathrm{~mm}$, inside diameter (ID) $0.9 \mathrm{~mm}$, and filament $0.1 \mathrm{~mm}$. The best success was achieved when the pipette resistance was 7 to 10 $\mathrm{M} \Omega$ in the standard recording solutions. High-resistance seals were also possible with blue-tipped microhematocrit capillaries of soda-lime glass (Thermo Fisher Scientific 22-362-574, ID 1.1 to $1.2 \mathrm{~mm}$, wall 0.18 to $0.22 \mathrm{~mm}$, no filament). However, the seals with the soda-lime glass were less stable, often breaking within two minutes.

During recording, the beads coated with cells were stored in a standard extracellular Ringer containing (in $\mathrm{mM}$ ) $\mathrm{NaCl}$ $140, \mathrm{KCl} 5, \mathrm{CaCl}_{2} 2, \mathrm{MgCl}_{2} 2$, sodium pyruvate 2 , 4-(2hydroxyethyl)-1-piperazineethanesulfonic acid (HEPES) 5, and D-glucose 9.4, adjusted to $\mathrm{pH} 7.4$ with $\mathrm{NaOH}$. The recording pipettes also contained this solution. After excision of the cilium, the first (standard) pseudointracellular solution used to bathe the cytoplasmic face of the excised cilium contained (in $\mathrm{mM}$ ) $\mathrm{KCl} 140, \mathrm{NaCl} 5, \mathrm{CaCl}_{2} 0.76, \mathrm{MgCl}_{2} 2$, HEPES 5, 1,2-bis(2-aminophenoxy)ethane- $N, N, N^{\prime}, N^{\prime}$ - 
tetraacetic acid (BAPTA) 2, and D-glucose 5, adjusted to $\mathrm{pH} 7.4$ with $\mathrm{KOH}$. The concentration of $\mathrm{Ca}_{\text {free }}^{2+}$ in this solution was $0.1 \mu \mathrm{M}$. In other pseudointracellular solutions, $\mathrm{Ca}_{\text {free }}^{2+}$ concentration was $3 \mu \mathrm{M}$ or $300 \mu \mathrm{M}$. For the former, 1,2-bis(2-amino-5-bromophenoxy)ethane- $N, N, N^{\prime}, N^{\prime}$ tetraacetic acid (dibromoBAPTA) was used instead of BAPTA.

All recordings were done under voltage-clamp at room temperature $\left(24^{\circ} \mathrm{C}\right)$. The recording pipette and chamber were coupled by $\mathrm{Ag} / \mathrm{AgCl}$ electrodes to an Axopatch 200B patch-clamp amplifier with a CV203BU headstage and Digidata 1200A BNC data-acquisition system, controlled by pCLAMP 5.7.1 software (all from Axon Instruments / Molecular Devices, Sunnyvale, CA USA). The pipette was positioned with an MO-103M hydraulic micromanipulator (Narishige, Tokyo, Japan). Currents were low-pass filtered at $2 \mathrm{kHz}$ and digitized at $5 \mathrm{kHz}$. Software for analysis included Origin 7.0 (OriginLab Corporation, Northampton, MA USA) and QuB 1.5 (http://www.qub.buffalo.edu, State University of New York, Buffalo, NY USA). Results of repeated experiments are reported as mean \pm standard error of the mean.

\section{Results}

\section{Preparation of cells with primary cilia}

To facilitate electrical recording, ciliated mIMCD-3 cells were grown on beads that were free to move within the recording chamber. This configuration allowed the full length of the cilium to follow suction applied through the recording micropipette until the pipette sealed near the base of the cilium. In culture, glass-coated beads (G102$<90$, diameter $63 \pm 2 \mu \mathrm{m}, n=50$, range 39 to $97 \mu \mathrm{m}$, SoloHill Engineering) became covered with ciliated cells (Figure 1A). At the equator of the bead, a few cilia projected clearly beyond the cell layer and could be seen with phase-contrast microscopy (Figure 1B). The diameter of a primary cilium is about $200 \mathrm{~nm}$ [41], near the limit of detection for a conventional light microscope. The fluorescent membrane dye di-8-ANEPPS (D3167, Invitrogen / Life Technologies) greatly enhanced the visibility of the live cilia (Figure 1C). However, we did not use dye or fluorescent visualization when recording because of possible phototoxicity to the cilia [42]. We confirmed that the extensions were primary cilia by immunostaining for acetylated $\alpha$-tubulin (Figure 1D) with an antibody that is a well-recognized marker of primary cilia [43]. Due to their specific gravity (1.028), the beads sank to the bottom of the chamber; this facilitated changes of growth medium and rinsing. When the beads were cultured in a chamber with a glass bottom, the beads became embedded in a cellular monolayer that prevented them from being harvested easily. When the beads and cells were cultured in a Teflon chamber (Figure 1E), many of the beads remained free of the monolayer.

\section{Electrical recording}

Beads coated with ciliated cells were placed in a recording chamber and observed under phase-contrast microscopy. By applying positive pressure through the recording micropipette, it was often possible to rotate a bead until a cilium was positioned near the tip of the pipette. Suction was then applied through the pipette to draw the single cilium into the pipette (Figure 2, Additional file 1). The cilium easily followed the suction because the bead was small and not attached to any surface. In $47 \%$ of 838 attempts, suction resulted in a membrane-pipette seal of resistance $\geq 1 \mathrm{G} \Omega$. With a cilium in the recording pipette and the cell still attached, bursts of single-channel activity were seen in a minority of cells, particularly at depolarizing potentials (Figure $3 \mathrm{~A}$ ).

If the pipette was raised briefly into the air, the cell was pulled off at the air-bath interface, while the cilium remained sealed inside the pipette in the inside-out recording configuration. The pipette and cilium were then quickly transferred through the air and immersed in a solution that bathed the cytoplasmic face of the membrane. Such transfers could be repeated many times without rupturing the seal. Initially each cilium was placed in a pseudointracellular bath containing $0.1 \mu \mathrm{M}$ free $\mathrm{Ca}^{2+}$. The current-voltage relation measured in this bath was linear (Figure 3B), and the input resistance averaged $12.1 \pm 0.4 \mathrm{G} \Omega$ (measured from -80 to $+60 \mathrm{mV}$; $n=222$, range 1.7 to $35 \mathrm{G} \Omega$ ). Even in low $\mathrm{Ca}^{2+}$, some of the cilia showed single-channel fluctuations at strongly depolarizing potentials (Figure 3B, blue; Figure 3C). A preliminary study of this channel indicated that it had a conductance of $92 \mathrm{pS}$ and a reversal potential of $-65 \mathrm{mV}$ in the standard recording solutions. It was activated by both depolarization and increasing cytoplasmic $\mathrm{Ca}^{2+}$ (Figure 3C). This channel was seen in $32 \%$ of 38 cilia tested but was not detected in any of seven patches taken from the apical cell membrane.

In $85 \%$ of 47 cilia tested, $300 \mu \mathrm{M}$ cytoplasmic free $\mathrm{Ca}^{2+}$ activated a second, distinct current (Figure 3D). Clear single-channel events could not be discriminated, suggesting that the current reflects the summated activities of a moderate number of smaller-conductance channels. The $\mathrm{Ca}^{2+}$-dependent macroscopic current showed pronounced outward rectification and reversed near $0 \mathrm{mV}$ in the standard recording solutions (Figure 3D). A similar current was seen in $77 \%$ of 13 patches taken from the apical cell membrane.

\section{Discussion}

Our goal was to allow the direct study of electrical signals in the membrane of a primary cilium. To develop a 


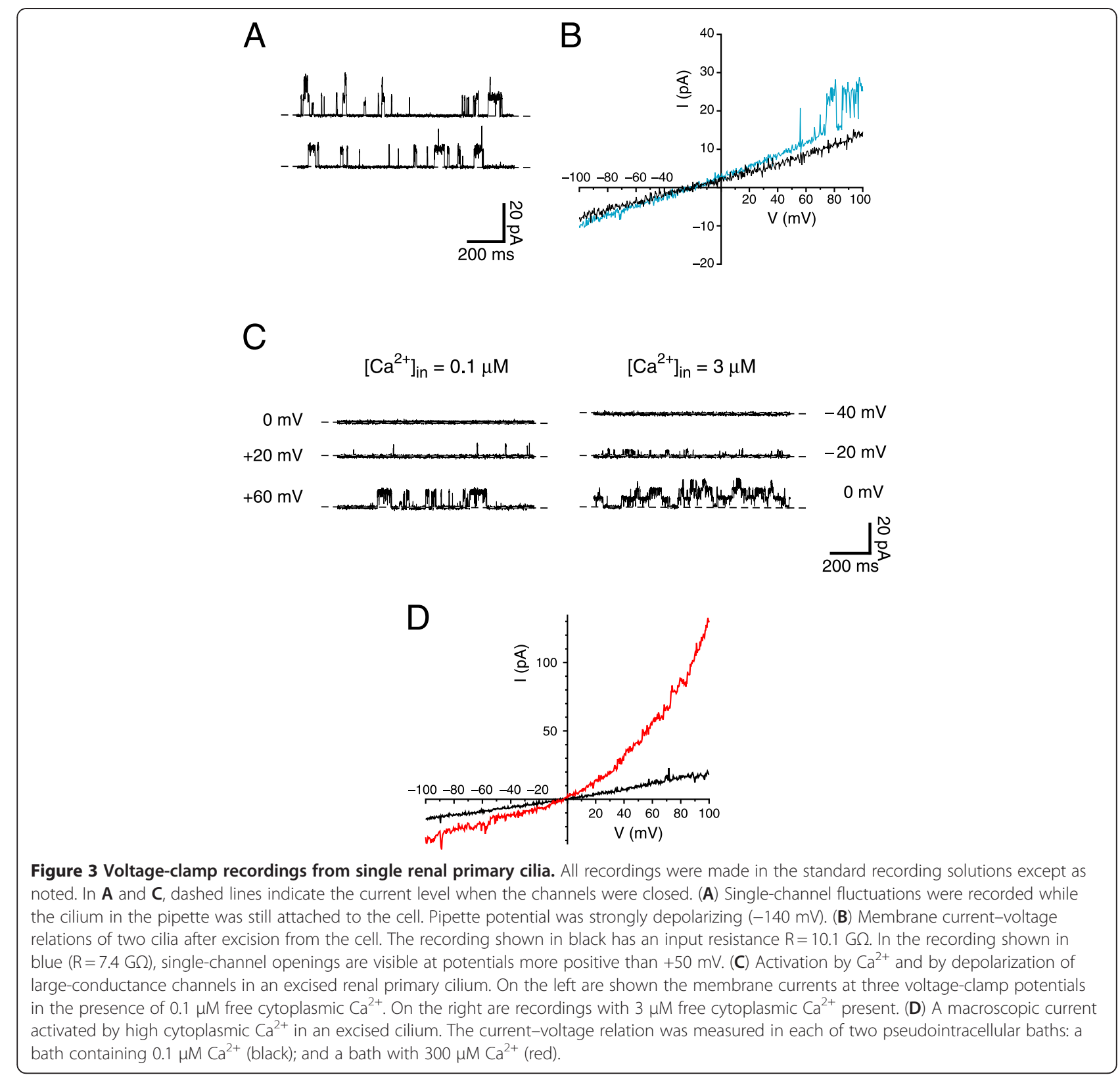

method for this, we selected the cilia of cultured renal epithelial cells for two reasons. First, as discussed below, an existing body of work has identified specific channels and receptors that are speculated to underlie sensory functions in renal cilia. Second, channel defects in renal cilia are implicated in cystic kidney diseases, including autosomal dominant polycystic kidney disease (ADPKD) [6], the most common monogenic renal disorder [44]. Most cases of ADPKD are caused by mutations in the genes [45] for either TRPP2, a channel protein located on the renal primary cilium, or polycystin-1, a ciliary molecule that interacts with TRPP2 [14,15,30,46,47].

In pilot studies, we were unable to record from the cilia of cells attached to fixed substrates such as cover glasses or folded filter paper [48]. On cover glasses, visual identification of the cilia was difficult because of the underlying cells. Even on folded filter paper, the base of the cilium could not be clearly seen. As a result, we were unable to move the recording pipette along the full length of a cilium to its base, where the pipette can seal to the membrane. This problem was overcome by growing the cells on a movable substrate, a glass-coated bead small enough to be easily moved by suction applied through the recording pipette. The full length of a cilium was able to follow this suction until the pipette sealed near the base of the cilium. Obtaining such seals was also possible with enzymatically dissociated cells, but that introduces a risk of enzymatic degradation of membrane proteins. 
It is of central importance to know that the primary cilium enters the recording pipette. This was evident from direct observation (Figure 2, Additional file 1). The initial recording studies also suggested the presence of a specialized membrane. We identified a large-conductance channel (Figure 3B,C) that was present in ciliary recordings but not in patches from the apical cell membrane. Although this method allows a focus on the ciliary membrane, it is likely that some plasma membrane surrounding the base of the cilium also enters the pipette [49]. Cytoplasmic effectors can be readily tested (for example, $\mathrm{Ca}^{2+}$, Figure 3C,D), and it is possible to apply external stimuli via intrapipette perfusion [50]. Two limitations apply to our method at present. First, the cilium inside the pipette cannot be bent with fluid flow, which limits the ability to study mechanical stimulation. Second, the method used to verify that the cilium has entered the pipette (see Methods, Electrical Recording) is very difficult with cilia shorter than $10 \mu \mathrm{m}$. In the future, an appropriate ciliary marker might allow visualization of even a short cilium within the recording pipette following recording.

The first direct recordings from the membrane of a primary cilium were reported by Raychowdhury et al. $[13,16]$. Primary cilia were isolated from cultured cells derived from porcine renal epithelium, and membrane patches were excised from the cilia. Our method offers three improvements. First, we record from each cilium while it is cell-attached or immediately after it is plucked from the cell. In the previous method [16], isolating the cilia by centrifugation took over two hours. The cilia were then frozen and thawed for subsequent use. Second, recording from small excised patches [16] samples the membrane and reduces the chances of observing channels expressed at low density or at specific loci on the cilia. We record from the entire membrane of one cilium. Finally, the authors of the published method noted that low input resistances constrained their analyses [16]. As indicated above, we achieve very high input resistances.

The growth of ciliated cells on beads may prove useful in applications other than electrophysiological recording. Proteins have been isolated and identified from single cells, but the sensitivity is not high [51]. It is conceivable, particularly with longer cilia and future improvements in proteomic techniques, that micropipettes could be used to isolate enough cilia from cell-coated beads to generate a primary ciliome. We estimate that 420 cilia, each $40 \mu \mathrm{m}$ long and $0.2 \mu \mathrm{m}$ in diameter, would have a combined volume equal to that of a single cell $10 \mu \mathrm{m}$ in diameter. An alternative approach would be to culture cells on beads in a spinner flask so that a large number of ciliated cells would be grown in a small space. Subsequent isolation of the cilia by established means [52] might suffice for the purpose of making a primary ciliome.
The method for recording from primary cilia was developed with cultured renal epithelial cells. We must acknowledge that cultured cells cannot perfectly represent the environment that exists in the inner medullary collecting duct of the murine kidney. There is evidence that protein localization to primary cilia is altered by environmental factors such as flow [53], availability of ligands [54], and serum deprivation [55]. However, culture conditions similar to ours have been successfully used by other researchers studying ciliary function in kidney cells $[28,56]$. In the future, it may be productive to use acutely dissociated preparations from patient samples despite the inherent risks of enzymatic damage to membrane proteins.

A technique that measures ciliary electrical activity will be useful in examining ciliary signaling pathways that use ion channels. Several channel proteins (TRPP2, TRPC1, TRPV4, $\alpha$-epithelial sodium channel) and receptors (for example, epidermal growth factor receptor, type 2 vasopressin receptor) have been localized to renal primary cilia [13-18,57]. A wide variety of renal stimuli have been shown to alter the activity of these channels: TRPP2 (fluid flow [12], epidermal growth factor [57], $\mathrm{pH}$ [58], voltage [58], cytoplasmic calcium [31,34]); the TRPP2/TRPC1 complex (G-protein coupled receptor agonists [17]); and the TRPP2/TRPV4 complex (heat, swelling, external calcium [18]). It seems likely that different cells will have different channels localized to their primary cilia for the transduction of different stimuli. For example, TRPP2 is present on the primary cilium of the following cells and has been hypothesized or shown to transduce mechanical stimuli: embryonic node cells, ovarian granulosa cells, cholangiocytes, vascular smooth muscle cells, and vascular endothelial cells [59-63]. TRPV4 is present on the primary cilia of cholangiocytes and mediates a response to changes in osmolarity [8]. In neurons, several receptors for channel-containing pathways have been localized to primary cilia (for example, melanin-concentrating hormone receptor $1[64,65])$, although corresponding ciliary channels have not yet been found. The utility of our method should increase when coupled with methods for manipulating the expression of ciliary proteins. Targeted ciliary expression has been possible in IMCD [54,66] and other cell lines [67-69]. Recording from cells treated to knock down ciliary channel proteins should aid in identifying subunits contributing to channel function.

It would be helpful to show that our method confirms previous descriptions of ciliary membrane channels. Because such reports are rare, comparison is difficult. Raychowdhury et al. reported a channel resembling the epithelial sodium channel $(\mathrm{ENaC})$ in cilia from the proximal tubule-like [70] cell line LLC-PK 1 [13]. Although ENaC has been found on the apical surface of cells from the inner 
medullary collecting duct [71], there are no reports of $\mathrm{ENaC}$ on the primary cilium in this portion of the nephron. We have not observed any constitutive $\mathrm{Na}^{+}$-selective current in the cilia of cells from the inner medullary collecting duct cell line mIMCD-3. The primary cilia of mIMCD-3 cells express the TRPC1 [17] and TRPP2 channel subunits $[17,32]$. In some systems, TRPP2 contributes to large-conductance channels that resemble the single channels we observed in mIMCD-3 cilia (Figure 3A-C). However, the properties of TRPP2-dependent channel currents vary considerably depending on the cellular system and physiological solutions chosen [13,16-18,29-34,57,58]. Ultimately knockdown studies will be required to learn the molecular composition of the large-conductance channel in native $\mathrm{MIMCD}-3$ cilia.

Methods for recording electrical events in the specialized cilia that underlie visual and olfactory sensation initiated over 20 years of rapid progress in both basic physiology and in the etiology of related human diseases (for example, retinitis pigmentosa and achromatopsia [21]). Our initial studies (Figure 3) indicate that the ability to record from single primary cilia may allow similar advances. In cases where primary cilia underlie the transduction of a stimulus into an electrical signal, the method reported here should allow a direct means of investigation.

\section{Conclusions}

We describe a novel method that allows for the first time electrical recording from a freshly isolated primary cilium with minimal contributions from other cellular compartments. Adherent cells were grown on small, spherical beads that could be easily moved within the recording chamber. In this configuration, an entire cilium could be pulled into a recording microelectrode. Many attempts yielded a seal with high input resistance and stability. Recording of ciliary electrical events was possible while attached to the cell and following excision of the cilium. Ciliary recording is a direct way to learn the effects of second messengers and voltage changes on ciliary transduction channels. It will enable resolution of the ambiguities that inevitably result from studies in non-native membranes. Ultimately, the culturing of ciliated cells on beads may also provide a means of gathering cilia for proteomics.

\section{Additional file}

Additional file 1: Video with six examples showing the method for electrical recording from an isolated primary cilium. In each example, a glass-coated bead is covered with a confluent layer of mIMCD-3 cells. One primary cilium of one cell can be seen entering the tip of the recording pipette.

\section{Competing interests}

The authors declare that they have no competing interests.

\section{Authors' contributions}

SJK and NKK designed the research and wrote the paper. NKK performed the cell culture, staining, and microscopy. SJK acquired electrophysiological data. Both authors read and approved the final manuscript.

\section{Acknowledgments}

We are grateful to John Bissler and Brian Siroky (Cincinnati Children's Hospital Medical Center) and Linda Parysek (University of Cincinnati) for helpful discussions. This work was supported by National Institutes of Health grant R21 DK091917 and by the University Research Council and the Department of Cancer and Cell Biology of the University of Cincinnati.

Received: 5 March 2012 Accepted: 30 May 2012

Published: 3 September 2012

\section{References}

1. Wheatley DN, Wang AM, Strugnell GE: Expression of primary cilia in mammalian cells. Cell Biol Int 1996, 20:73-81.

2. Veland IR, Awan A, Pedersen LB, Yoder BK, Christensen ST: Primary cilia and signaling pathways in mammalian development, health and disease. Nephron Physiol 2009, 111:39-53.

3. Lancaster MA, Gleeson JG: The primary cilium as a cellular signaling center: lessons from disease. Curr Opin Genet Dev 2009, 19:220-229.

4. Louvi A, Grove EA: Cilia in the CNS: the quiet organelle claims center stage. Neuron 2011, 69:1046-1060.

5. Ware SM, Aygun MG, Hildebrandt F: Spectrum of clinical diseases caused by disorders of primary cilia. Proc Am Thorac Soc 2011, 8:444-450.

6. Gascue C, Katsanis N, Badano JL: Cystic diseases of the kidney: ciliary dysfunction and cystogenic mechanisms. Pediatr Nephrol 2011, 26:1181-1195.

7. Pazour GJ, Witman GB: The vertebrate primary cilium is a sensory organelle. Curr Opin Cell Biol 2003, 15:105-110.

8. Gradilone SA, Masyuk Al, Splinter PL, Banales JM, Huang BQ, Tietz PS, Masyuk TV, LaRusso NF: Cholangiocyte cilia express TRPV4 and detect changes in luminal tonicity inducing bicarbonate secretion. Proc Natl Acad Sci USA 2007, 104:19138-19143.

9. Moorman SJ, Shorr AZ: The primary cilium as a gravitational force transducer and a regulator of transcriptional noise. Dev Dyn 2008, 237:1955-1959.

10. Berbari NF, O'Connor AK, Haycraft CJ, Yoder BK: The primary cilium as a complex signaling center. Curr Biol 2009, 19:R526-R535.

11. Satir P, Pedersen LB, Christensen ST: The primary cilium at a glance. J Cell Sci 2010, 123:499-503.

12. Nauli SM, Alenghat FJ, Luo Y, Williams E, Vassilev P, Li X, Elia AEH, Lu W, Brown EM, Quinn SJ, Ingber DE, Zhou J: Polycystins 1 and 2 mediate mechanosensation in the primary cilium of kidney cells. Nat Genet 2003, 33:129-137.

13. Raychowdhury MK, Ramos AJ, Zhang P, McLaughin M, Dai X-Q, Chen X-Z, Montalbetti N, Cantero MDR, Ausiello DA, Cantiello HF: Vasopressin receptor-mediated functional signaling pathway in primary cilia of renal epithelial cells. Am J Physiol 2009, 296:F87-F97.

14. Pazour GJ, San Agustin JT, Follit JA, Rosenbaum JL, Witman GB: Polycystin-2 localizes to kidney cilia and the ciliary level is elevated in orpk mice with polycystic kidney disease. Curr Biol 2002, 12:R378-R380.

15. Yoder BK, Hou X, Guay-Woodford LM: The polycystic kidney disease proteins, polycystin-1, polycystin-2, polaris, and cystin, are co-localized in renal cilia. J Am Soc Nephrol 2002, 13:2508-2516.

16. Raychowdhury MK, McLaughlin M, Ramos AJ, Montalbetti N, Bouley R, Ausiello DA, Cantiello HF: Characterization of single channel currents from primary cilia of renal epithelial cells. J Biol Chem 2005, 280:34718-34722.

17. Bai C-X, Giamarchi A, Rodat-Despoix L, Padilla F, Downs T, Tsiokas L, Delmas $P$ : Formation of a new receptor-operated channel by heteromeric assembly of TRPP2 and TRPC1 subunits. EMBO Rep 2008, 9:472-479.

18. Köttgen M, Buchholz B, Garcia-Gonzalez MA, Kotsis F, Fu X, Doerken M, Boehlke C, Steffl D, Tauber R, Wegierski T, Nitschke R, Suzuki M, KramerZucker A, Germino GG, Watnick T, Prenen J, Nilius B, Kuehn EW, Walz G: TRPP2 and TRPV4 form a polymodal sensory channel complex. J Cell Biol 2008, 182:437-447.

19. Ren D, Navarro B, Perez G, Jackson AC, Hsu S, Shi Q, Tilly JL, Clapham DE: A sperm ion channel required for sperm motility and male fertility. Nature 2001, 413:603-609. 
20. Fujiu K, Nakayama Y, Yanagisawa A, Sokabe M, Yoshimura K: Chlamydomonas CAV2 encodes a voltage-dependent calcium channe required for the flagellar waveform conversion. Curr Biol 2009, 19:133-139.

21. Biel M, Michalakis S: Cyclic nucleotide-gated channels. Handb Exp Pharmacol 2009, 191:111-136

22. Nakamura T, Gold GH: A cyclic nucleotide-gated conductance in olfactory receptor cilia. Nature 1987, 325:442-444.

23. Kleene SJ: Origin of the chloride current in olfactory transduction. Neuron 1993, 11:123-132.

24. Inglis PN, Boroevich KA, Leroux MR: Piecing together a ciliome. Trends Genet 2006, 22:491-500.

25. Gherman A, Davis EE, Katsanis N: The ciliary proteome database: an integrated community resource for the genetic and functional dissection of cilia. Nat Genet 2006, 38:961-962.

26. Li G, Vega R, Nelms K, Gekakis N, Goodnow C, McNamara P, Wu H, Hong NA, Glynne R: A role for Alström syndrome protein, alms1, in kidney ciliogenesis and cellular quiescence. PLoS Genet 2007, 3:e8.

27. Arnaiz O, Malinowska A, Klotz C, Sperling L, Dadlez M, Koll F, Cohen J: Cildb: a knowledgebase for centrosomes and cilia. Database (Oxford) 2009, 2009:bap022.

28. Praetorius HA, Spring KR: Removal of the MDCK cell primary cilium abolishes flow sensing. J Membr Biol 2003, 191:69-76.

29. Hanaoka K, Qian F, Boletta A, Bhunia AK, Piontek K, Tsiokas L, Sukhatme VP, Guggino WB, Germino GG: Co-assembly of polycystin-1 and -2 produces unique cation-permeable currents. Nature 2000, 408:990-994.

30. González-Perrett S, Kim K, Ibarra C, Damiano AE, Zotta E, Batelli M, Harris PC, Reisin IL, Arnaout MA, Cantiello HF: Polycystin-2, the protein mutated in autosomal dominant polycystic kidney disease (ADPKD), is a $\mathrm{Ca}^{2+}$-permeable nonselective cation channel. Proc Natl Acad Sci USA 2001, 98:1182-1187

31. Vassilev PM, Guo L, Chen X-Z, Segal Y, Peng J-B, Basora N, Babakhanlou H, Cruger G, Kanazirska M, Ye C-P, Brown EM, Hediger MA, Zhou J: Polycystin2 is a novel cation channel implicated in defective intracellular $\mathrm{Ca}^{2+}$ homeostasis in polycystic kidney disease. Biochem Biophys Res Commun 2001, 282:341-350

32. Luo Y, Vassilev PM, Li X, Kawanabe $Y$, Zhou J: Native polycystin 2 functions as a plasma membrane $\mathrm{Ca}^{2+}$-permeable cation channel in renal epithelia. Mol Cell Biol 2003, 23:2600-2607.

33. Delmas P, Nauli SM, Li X, Coste B, Osorio N, Crest M, Brown DA, Zhou J: Gating of the polycystin ion channel signaling complex in neurons and kidney cells. FASEB J 2004, 18:740-742.

34. Koulen P, Cai Y, Geng L, Maeda Y, Nishimura S, Witzgall R, Ehrlich BE, Somlo S: Polycystin-2 is an intracellular calcium release channel. Nat Cell Biol 2002, 4:191-197.

35. Cantiello HF: Regulation of calcium signaling by polycystin-2. Am J Physiol 2004, 286:F1012-F1029.

36. Tsiokas L, Kim S, Ong E-C: Cell biology of polycystin-2. Cell Signal 2007, 19:444-453.

37. Witzgall R: TRPP2 channel regulation. Handb Exp Pharmacol 2007, 179:363-375.

38. Kleene SJ, Gesteland RC: Transmembrane currents in frog olfactory cilia. J Membr Biol 1991, 120:75-81.

39. Rauchman MI, Nigam SK, Delpire E, Gullans SR: An osmotically tolerant inner medullary collecting duct cell line from an SV40 transgenic mouse. Am J Physiol 1993, 265:F416-F424.

40. Kleene SJ: Patch-clamping of whole olfactory cilia, In Experimental Cell Biology of Taste and Olfaction/Current Techniques and Protocols. Edited by Spielman Al, Brand JG. Boca Raton, FL: CRC Press; 1995:347-352.

41. Barnes BG: Ciliated secretory cells in the pars distalis of the mouse hypophysis. J Ultrastruc Res 1961, 5:453-467.

42. Takeuchi $H$, Kurahashi T: Distribution, amplification, and summation of cyclic nucleotide sensitivities within single olfactory sensory cilia. J Neurosci 2008, 28:766-775.

43. LeDizet M, Piperno G: Detection of acetylated a-tubulin by specific antibodies. Meth Enzymol 1991, 196:264-274.

44. Zhou J: Polycystins and primary cilia: primers for cell cycle progression. Annu Rev Physiol 2009, 71:83-113.

45. Rossetti S, Consugar MB, Chapman AB, Torres VE, Guay-Woodford LM, Grantham JJ, Bennett WM, Meyers CM, Walker DL, Bae K, Zhang Q, Thompson PA, Miller JP, Harris PC, the CRISP Consortium: Comprehensive molecular diagnostics in autosomal dominant polycystic kidney disease. J Am Soc Nephrol 2007, 18:2143-2160.

46. Tsiokas L, Kim E, Arnould T, Sukhatme VP, Walz G: Homo- and heterodimeric interactions between the gene products of PKD1 and PKD2. Proc Natl Acad Sci USA 1997, 94:6965-6970.

47. Qian F, Germino FJ, Cai Y, Zhang X, Somlo S, Germino GG: PKD1 interacts with PKD2 through a probable coiled-coil domain. Nat Genet 1997, 16:179-183.

48. Roth KE, Rieder CL, Bowser SS: Flexible-substratum technique for viewing cells from the side: some in vivo properties of primary $(9+0)$ cilia in cultured kidney epithelia. J Cell Sci 1988, 89:457-466.

49. Suchyna TM, Markin VS, Sachs F: Biophysics and structure of the patch and the gigaseal. Biophys J 2009, 97:738-747.

50. Kleene SJ: Basal conductance of frog olfactory cilia. Pflugers Arch 1992, 421:374-380.

51. Dovichi NJ, Hu S, Michels D, Mao D, Dambrowitz A: Single cell proteomics, In Single Cell Analysis: Technologies and Applications. Edited by Anselmetti D. Weinheim, Germany: WILEY-VCH Verlag GmbH \& Co; 2009:69-89.

52. Mitchell KAP, Szabo G, Otero AS: Methods for the isolation of sensory and primary cilia-an overview. Methods Cell Biol 2009, 94:87-101.

53. Low SH, Vasanth S, Larson CH, Mukherjee S, Sharma N, Kinter MT, Kane ME, Obara T, Weimbs T: Polycystin-1, STAT6, and P100 function in a pathway that transduces ciliary mechanosensation and is activated in polycystic kidney disease. Dev Cell 2006, 10:57-69.

54. Domire JS, Green JA, Lee KG, Johnson AD, Askwith CC, Mykytyn K: Dopamine receptor 1 localizes to neuronal cilia in a dynamic process that requires the Bardet-Biedl syndrome proteins. Cell Mol Life Sci 2011, 68:2951-2960

55. Schneider L, Clement CA, Teilmann SC, Pazour GJ, Hoffmann EK, Satir P, Christensen ST: PDGFRaa signaling is regulated through the primary cilium in fibroblasts. Curr Biol 2005, 15:1861-1866.

56. Praetorius HA, Spring KR: Bending the MDCK cell primary cilium increases intracellular calcium. J Membr Biol 2001, 184:71-79.

57. Ma R, Li W-P, Rundle D, Kong J, Akbarali HI, Tsiokas L: PKD2 functions as an epidermal growth factor-activated plasma membrane channel. Mol Cell Biol 2005, 25:8285-8298.

58. González-Perrett S, Batelli M, Kim K, Essafi M, Timpanaro G, Moltabetti N, Reisin IL, Arnaout MA, Cantiello HF: Voltage dependence and pH regulation of human polycystin-2-mediated cation channel activity. J Biol Chem 2002, 277:24959-24966.

59. McGrath J, Somlo S, Makova S, Tian X, Brueckner M: Two populations of node monocilia initiate left-right asymmetry in the mouse. Cell 2003, 114:61-73.

60. Teilmann SC, Byskov AG, Pedersen PA, Wheatley DN, Pazour GJ, Christensen ST: Localization of transient receptor potential ion channels in primary and motile cilia of the female murine reproductive organs. Mol Reprod Dev 2005, 71:444-452.

61. Masyuk Al, Masyuk TV, Splinter PL, Huang BQ, Stroope AJ, LaRusso NF: Cholangiocyte cilia detect changes in luminal fluid flow and transmit them into intracellular $\mathrm{Ca}^{2+}$ and cAMP signaling. Gastroenterology 2006, 131:911-920.

62. Lu CJ, Du H, Wu J, Jansen DA, Jordan KL, Xu N, Sieck GC, Qian Q: Nonrandom distribution and sensory functions of primary cilia in vascular smooth muscle cells. Kidney Blood Press Res 2008, 31:171-184.

63. AbouAlaiwi WA, Takahashi M, Mell BR, Jones TJ, Ratnam S, Kolb RJ, Nauli SM: Ciliary polycystin-2 is a mechanosensitive calcium channel involved in nitric oxide signaling cascades. Circ Res 2009, 104:860-869.

64. Berbari NF, Johnson AD, Lewis JS, Askwith CC, Mykytyn K: Identification of ciliary localization sequences within the third intracellular loop of $G$ protein-coupled receptors. Mol Biol Cell 2008, 19:1540-1547.

65. Eberle AN, Mild G, Zumsteg U: Cellular models for the study of the pharmacology and signaling of melanin-concentrating hormone receptors. J Recept Signal Transduct Res 2010, 30:385-402.

66. Tao B, Bu S, Yang Z, Siroky B, Kappes JC, Kispert A, Guay-Woodford LM: Cystin localizes to primary cilia via membrane microdomains and a targeting motif. J Am Soc Nephrol 2009, 20:2570-2580.

67. Jenkins PM, Hurd TW, Zhang L, McEwen DP, Brown RL, Margolis B, Verhey $\mathrm{KJ}$, Martens JR: Ciliary targeting of olfactory CNG channels requires the CNGB1b subunit and the kinesin-2 motor protein, KIF17. Curr Biol 2006, 16:1211-1216

68. Domire JS, Mykytyn K: Markers for neuronal cilia. Methods Cell Biol 2009 91:111-121. 
69. Marley A, von Zastrow M: DISC1 regulates primary cilia that display specific dopamine receptors. PLOS One 2010, 5:e10902.

70. Rabito CA: Occluding junctions in a renal cell line (LLC-PK 1$)$ with characteristics of proximal tubular cells. Am J Physiol 1986, 250:F734-F743.

71. Volk KA, Sigmund RD, Snyder PM, McDonald FJ, Welsh MJ, Stokes JB: rENaC is the predominant $\mathrm{Na}^{+}$channel in the apical membrane of the rat renal inner medullary collecting duct. J Clin Invest 1995, 96:2748-2757.

doi:10.1186/2046-2530-1-17

Cite this article as: Kleene and Kleene: A method for measuring

electrical signals in a primary cilium. Cilia 2012 1:17.

\section{Submit your next manuscript to BioMed Central and take full advantage of:}

- Convenient online submission

- Thorough peer review

- No space constraints or color figure charges

- Immediate publication on acceptance

- Inclusion in PubMed, CAS, Scopus and Google Scholar

- Research which is freely available for redistribution 